\title{
LOCAL ANTIOXIDANT EFFECT OF ORIGINAL DERMAL FILM WITH MELATONIN IN THERMAL INJURY
}

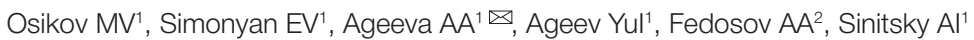

South Ural State Medical University, Chelyabinsk, Russia

2 Pirogov Russian National Research Medical University, Moscow, Russia

Oxidative stress (OS) escalation associated with thermal trauma (TT) and pleiotropic effects of melatonin (MT) suggest a study of protective properties of the latter when applied as part of a novel dermal film (DF) to skin burns. This work aimed to assess the content of OS markers in the skin subjected to experimental TT and treated with DF with MT. Third A degree TT (area of 3.5\%) were modeled by immersing a patch of skin in boiling water. Twelve $\mathrm{cm}^{2}$ of DF with $5 \mathrm{mg} / \mathrm{g}$ of MT were applied daily for 5 days. The parameters calculated were wound's area and epithelializatiohon rate. The products monitored in the burn wound were lipid peroxidation (LPO) products in heptane and isopropanol phases of the lipid extract and protein oxidative modification (POM) products, the modification being spontaneous and metal-dependent. With TT in the wound, the content of secondary and end LPO products in heptane and isopropanol phases increased on the 5th and 10th days; the total content of POM products grew on the $5^{\text {th }}$ day (primary products, neutral) and on the $10^{\text {th }}$ day (primary and secondary products, neutral). Application of DF to a TT wound reduced the burn area, increased the epithelialization rate (by the $10^{\text {th }}$ day, the median went from $1.90 \%$ to $6.57 \%$; $p<0.05$ ), reduced the content of secondary and end LPO products in isopropanol phase (by the $10^{\text {th }}$ day, the median went from 0.007 to 0.004 u.0.i; $p<0.05$ ), reduced the total content of OMP products, namely that of primary neutral products - on the $5^{\text {th }}$ day, of primary and secondary neutral products - on the $10^{\text {th }}$ day. With TT present in the context of MT application, the burn area showed presence of secondary LPO products in heptane and isopropanol phases, LPO end products in isopropanol phase, POM products in the wound (basic and neutral primary/secondary POM products).

Keywords: thermal trauma, oxidative stress, melatonin, dermal film

Author contribution: MV Osikov — study concept and design, integrated analysis of the data obtained, authoring, manuscript editing; EV Simonyan — experimental material collection, analysis of the data obtained; AA Ageeva - experimental material collection, statistical processing and analysis of the data obtained, authoring; Yul Ageev - experimental material collection, statistical processing and analysis of the data obtained; AA Fedosov — analysis of the results, manuscript editing; Al Sinitsky - experimental material collection, manuscript editing.

Compliance with ethical standards: the study was approved by the Ethics Committee of the South Ural State Medical University, Chelyabinsk (Minutes \#10 of November 15, 2019), carried out in standard vivarium conditions with strict adherence to the requirements for animal keeping and care, as well as withdrawal of animals from the experiment and subsequent disposal in accordance with the European Convention for the Protection of Vertebrate Animals used for Experimental or Other Scientific Purposes (ETS № 123 of March 18, 1986, Strasbourg), EC Recommendations 2007/52/EC of June 18, 2007 outlining procedures of keeping and care for animals used for experimental and other scientific purposes, as well as the European Parliament and EU Council Directive 2010/63/EU of September 22, 2010 on protection of animals used for scientific purposes as governed by the rules of humane treatment of animals, guidelines for their withdrawal from experiments and euthanasia.

$\triangle$ Correspondence should be addressed: Anna A. Ageeva

Vorovskogo, 64, Chelyabinsk, 454092; anne.ageeva.r@yandex.ru

Received: 03.10.2020 Accepted: 23.10.2020 Published online: 10.11.2020

DOI: $10.24075 / \mathrm{brsmu} .2020 .070$

\section{ЛОКАЛЬНЫЙ АНТИОКСИДАНТНЫЙ ЭФФЕКТ ОРИГИНАЛЬНОЙ ДЕРМАЛЬНОЙ ПЛЕНКИ С МЕЛАТОНИНОМ ПРИ ТЕРМИЧЕСКОЙ ТРАВМЕ}

М. В. Осиков ${ }^{1}$, Е. В. Симонян ${ }^{1}$, А. А. Агеева ${ }^{1} \bowtie$ Ю. Ю. Агеев ${ }^{1}$, А. А. Федосов ${ }^{2}$, А. И. Синицкий

1 Южно-Уральский государственный медицинский университет, Челябинск, Россия

2 Российский национальный исследовательский медицинский университет имени Н. И. Пирогова, Москва, Россия

Эскалация оксидативного стресса (ОС) при термической травме (ТT) и плейотропные эффекты мелатонина (МТ) являются предпосылкой для изучения его протекторных свойств в составе новой дермальной пленки (ДП) при ожогах кожи. Цель работы - оценить содержание маркеров ОС в коже при экспериментальной ТТ и применении ДП с МТ. ТТ ІІА степени площадью 3,5\% моделировали погружением участка кожи в кипящую воду. ДП площадью

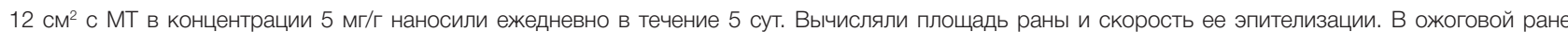
определяли продукты пероксидного окисления липидов (ПОЛ) в гептановой и изопропанольной фазах липидного экстракта, продукты окислительной модификации белков (ОМБ) в спонтанном и металл-зависимом режимах. При Пт в ране на 5-е и 10-е сут. увеличилось содержание вторичных и конечных продуктов ПОЛ в гептановой и изопропанольной фазах, суммарное содержание продуктов ОМБ за счет первичных продуктов нейтрального характера на 5-е сут., первичных и вторичных продуктов нейтрального характера на 10-е сут. Применение ДП при ПТ уменьшило площадь ожога, увеличило скорость эпителизации раны (на 10-е сут. по медиане с 1,90\% до 6,57\%; p < 0,05), снизило содержание в изопропанольной фазе вторичных и конечных (на 10-е сут. по медиане с 0,007 до 0,004 е.и.о.; p < 0,05) продуктов ПОЛ, снизило суммарное содержание продуктов ОМБ на 5-е сут. за счет первичных продуктов нейтрального характера, на 10-е сут. за счет первичных и вторичных продуктов нейтрального характера. При ПТ в условиях применения МТ площадь ожога ассоциирована с содержанием в ране вторичных продуктов ПОЛ в гептановой и изопропанольной фазах, конечных продуктов ПОЛ в изопропанольной фазе, суммарным содержанием продуктов ОМБ, содержанием первичных, вторичных, основного и нейтрального характера продуктов ОМБ.

Ключевые слова: термическая травма, окислительный стресс, мелатонин, дермальная пленка

Вклад авторов: М. В. Осиков - концепция и дизайн исследования, интегральный анализ полученных данных, написание текста, редактирование рукописи; Е. В. Симонян - набор экспериментального материала, анализ полученных данных; А. А. Агеева - набор экспериментального материала, статистическая обработка и анализ полученных данных, написание текста; Ю. И. Агеев - набор экспериментального материала, статистическая обработка и анализ полученных данных; А. А. Федосов - анализ результатов, редактирование рукописи; А. И. Синицкий - набор экспериментального материала, редактирование рукописи.

Соблюдение этических стандартов: исследование одобрено этическим комитетом Южно-Уральского государственного медицинского университета г. Челябинск (протокол № 10 от 15 ноября 2019 г.), выполнено в стандартных условиях вивария при строгом соблюдении требований по уходу и содержанию животных, а также выводу их из эксперимента с последующей утилизацией в соответствии с Европейской конвенцией о защите позвоночных животных, используемых для экспериментов или в иных научных целях (ЕTS № 123 от 18 марта 1986 г., Страсбург), Рекомендациями Европейской комиссии 2007/526/EC от 18 июня 2007 г. по содержанию и уходу за животными, используемыми в экспериментальных и других научных целях, а также Директивой 2010/63/EU Европейского парламента и совета Европейского союза от 22 сентября 2010 г. по охране животных, используемых в научных целях в соответствии с правилами гуманного отношения к животным, методическими рекомендациями по их выведению из опыта и эвтаназии.

$\bowtie$ Для корреспонденции: Анна Алексеевна Агеева

ул. Воровского, д. 64, г. Челябинск, 454092; anne.ageeva.r@yandex.ru

Статья получена: 03.10.2020 Статья принята к печати: 23.10.2020 Опубликована онлайн: 10.11.2020 DOI: $10.24075 /$ vrgmu.2020.070 
There are about 250,000 burn cases registered in the Russian Federation annually. About $80 \%$ of them are associated with thermal trauma (TT) [1]. The most common causes of $\Pi$ are hot liquids and flame; two-thirds of patients have the burn area smaller than $10 \%$ of the body surface [2]. Studying pathophysiology of burn wounds allows finding ways to halt their progression and develop new, pathogenetically valid methods of safe necrectomy and wound closure, modern substitutes. Burn wound healing rate, adverse outcome and development of TT-related complications depend not only on the injury's area and depth, severity of inflammation, acute phase response and immune reactions, but also on the local redox status [3]. For free radicals, the key targets in the skin are lipids and proteins. The "attacks" produce metabolites of lipid peroxidation (LPO) and protein oxidative modification (POM), respectively. As reported earlier, LPO products contribute to DNA damage, mutagenic and carcinogenic effects, modification of membrane proteins, enzymes, signaling molecules [4]. In the $\Pi$ pathogenesis, the relationship between inflammation and redox status under the OxInflammation concept describes the prooxidative potential of the lesion with positive feedback from inflammatory process events, cross-interactions of inflammatory mediators and redox status with possible progressions into SIRS [5]. Among the biomarkers of OxInflammation are lipid hydroperoxides 4-hydroxy-2-nonenal and malonic dialdehyde, carbonyl derivatives of 3-nitrotyrosine proteins, hydroxyguanosine etc. In pathological situations, identification of aldehyde- or ketonecontaining carbonyl derivatives of proteins (POM products) and LPO products (as markers of oxidative stress and performance of antioxidants) is of great interest [6].

Currently, there is a number of types of wound dressings applied as treatment of localized thermal skin injuries. Such dressings ease pain during bandaging, make the wound moist and thus promote cell differentiation and effective intercellular interaction, and shorten treatment time. There are absorbent dressings, atraumatic (usually tulle) dressings of natural fibers, powder (xerogel) dressings, spongy dressings made of porous material, hydrogel dressings made of insoluble polymers, hydrocolloidal dressings made of gel-forming substances, film dressings made of semipermeable polymer materials, etc [7]. No dressing is universal; its choice depends on the wound's stage, the degree of exudation and complications, if any. About $80 \%$ of wound dressings are made by foreign manufacturers, which makes research and development of an original dermal film (DF) relevant and promising. The films may incorporate various pharmacologically active substances (antimicrobial, antiseptic, analgesic, etc.); endogenous regulators of homeostasis with pleiotropic properties are particularly interesting [8-11]. In addition to its capacity to regulate rhythms of sleep and wakefulness, melatonin (MT) can produce multitropic effects and possesses antioxidant, pro- and anti-inflammatory, immunomodulatory, antiapoptogenic, cell proliferation and differentiation regulating, anti-aging and other properties, which make it attractive as a therapeutic agent [12]. There are no papers published and available that mention local use of MT as a part of DF applied to $T$.

This study aimed to assess the content of oxidative stress markers in the skin subjected to experimental $\Pi T$ and treated with original DF with MT.

\section{METHODS}

The experiment involved 88 male Wistar rats weighing 200-240 g. The animals were randomly divided into three groups: group 1 $(n=20)$ - intact control; group $2(n=36)$ - animals with TT; group $3(n=32)$ - animals with TT and DF with MT applied to the wound. Third degree A $\Pi T$ burns with a relative area of $3.5 \%$ were imposed in the interscapular area by immersion in purified water at $98-99^{\circ} \mathrm{C}$ for $12 \mathrm{~s}$. Depth of the burn was verified by morphological methods. Experimental model relying on hot water is most often considered by researchers as the TT standard. Zoletil 100 (tiletamine, zolazepam) (Virbac Sante Animale; France), dose of $20 \mathrm{mg} / \mathrm{kg}$, was the anesthetic used in the experiment. Subjects of the 3rd group received a $12 \mathrm{~cm}^{2}$ patch of the film with MT immediately after $\Pi \mathrm{w}$ was inflicted. The film was fixed with an aseptic bandage, changed daily for 5 days. Preliminary studies yielded DF composition based on sodium carboxymethylcellulose (poly-1,4- $\beta$-O-carboxymethylD-pyranosyl-D-sodium glycopyranose). The film was enriched with MT $(5 \mathrm{mg} / \mathrm{g})$, after which its pharmacological and technological parameters were evaluated, namely: organoleptic indicators (type, color, transparency, elasticity, presence of impurities and microcracks), adhesiveness, mechanical tensile strength, thickness (patent application \#2020118766). A Nikon Coolpix S2800 camera (Nikon; China) and Microsoft Office Visio software package (Microsoft; USA) enabled digital planimetry that allowed establishing the wound area 24 hours later, on the $5^{\text {th }}$ and $10^{\text {th }}$ days after $T$ infliction. The epithelialization rate (VS) was calculated using the following formula: $V S=S-S n / t$, where $S$ is the initial wound area before treatment (hereinafter, area at previous measurement); $S n$ is the area at subsequent measurement; $t$ is the number of days between measurements. The area of the wound at subsequent measurements was determined in \%, with $100 \%$ being the area before treatment. The results of the measurement were expressed in \%/day.

To prepare $10 \%$ skin homogenate, the burn wound was excised, immersed in a cooled $0.1 \mathrm{M}$ phosphate buffer solution (pH 7.4), after that about $40 \mathrm{mg}$ of tissue was homogenized in a glass mechanical homogenizer (1: 10 ratio) for 3 min at $4{ }^{\circ} \mathrm{C}$, which finally yielded $1 \mathrm{ml}$ of the homogenate. SF-56 spectrophotometer (LOMO-Spectr; St. Petersburg) was used to determine the content of LPO products in the homogenate;

Table 1. Influence of MT as part of DF on the parameters of healing of the wound, with experimental $T T\left(M e\left(Q_{25} ; Q_{75}\right)\right)$

\begin{tabular}{|c|c|c|c|c|}
\hline Indicator & $\begin{array}{l}\text { Group } 2 \\
\text { TT, } 5^{\text {th }} \text { day } \\
(n=16)\end{array}$ & $\begin{array}{c}\text { Group } 2 \\
\mathrm{TT}, 10^{\text {th }} \text { day } \\
(n=20)\end{array}$ & $\begin{array}{c}\text { Group } 3 \\
\mathrm{TT}+\mathrm{MT}, 5^{\text {th }} \text { day } \\
(n=16)\end{array}$ & $\begin{array}{c}\text { Group } 3 \\
\mathrm{TT}+\mathrm{MT}, 10^{\text {th }} \text { day } \\
(n=16)\end{array}$ \\
\hline Burn area, $\mathrm{cm}^{2}$ & $\begin{array}{c}11.66 \\
(11.50 ; 11.94)\end{array}$ & $\begin{array}{c}9.48 \\
(9.28 ; 9.93)^{\star}\end{array}$ & $\begin{array}{c}10.33 \\
(10.17 ; 10.56)^{\#}\end{array}$ & $\begin{array}{c}8.34 \\
(8.19 ; 8.51)^{\#}\end{array}$ \\
\hline Relative area, \% & $\begin{array}{c}3.34 \\
(3.25 ; 3.39)\end{array}$ & $\begin{array}{c}3.17 \\
(3.10 ; 3.29)^{*}\end{array}$ & $\begin{array}{c}3.36 \\
(3.23 ; 3.42)\end{array}$ & $\begin{array}{c}3.02 \\
(2.91 ; 3.13)^{\#}\end{array}$ \\
\hline Epithelialization rate, \%/day & $\begin{array}{c}0.89 \\
(0.86 ; 0.89)\end{array}$ & $\begin{array}{c}1.90 \\
(1.88 ; 1.95)^{\star}\end{array}$ & $\begin{array}{c}1.33 \\
(1.29 ; 1.35)^{\#}\end{array}$ & $\begin{array}{c}6.57 \\
(5.92 ; 6.93)^{\#}\end{array}$ \\
\hline Wound area shrinkage, \% & $\begin{array}{c}2.61 \\
(2.59 ; 2.64)\end{array}$ & $\begin{array}{c}3.68 \\
(3.53 ; 4.23)^{*}\end{array}$ & $\begin{array}{c}9.80 \\
(9.64 ; 10.08)^{*}\end{array}$ & $\begin{array}{c}16.10 \\
(14.62 ; 17.73)^{\#}\end{array}$ \\
\hline
\end{tabular}

Note: * - statistically significant $(p<0.05)$ differences with group 2 on the $5^{\text {th }}$ day; ${ }^{*}$ - with group 2 on the corresponding day. 


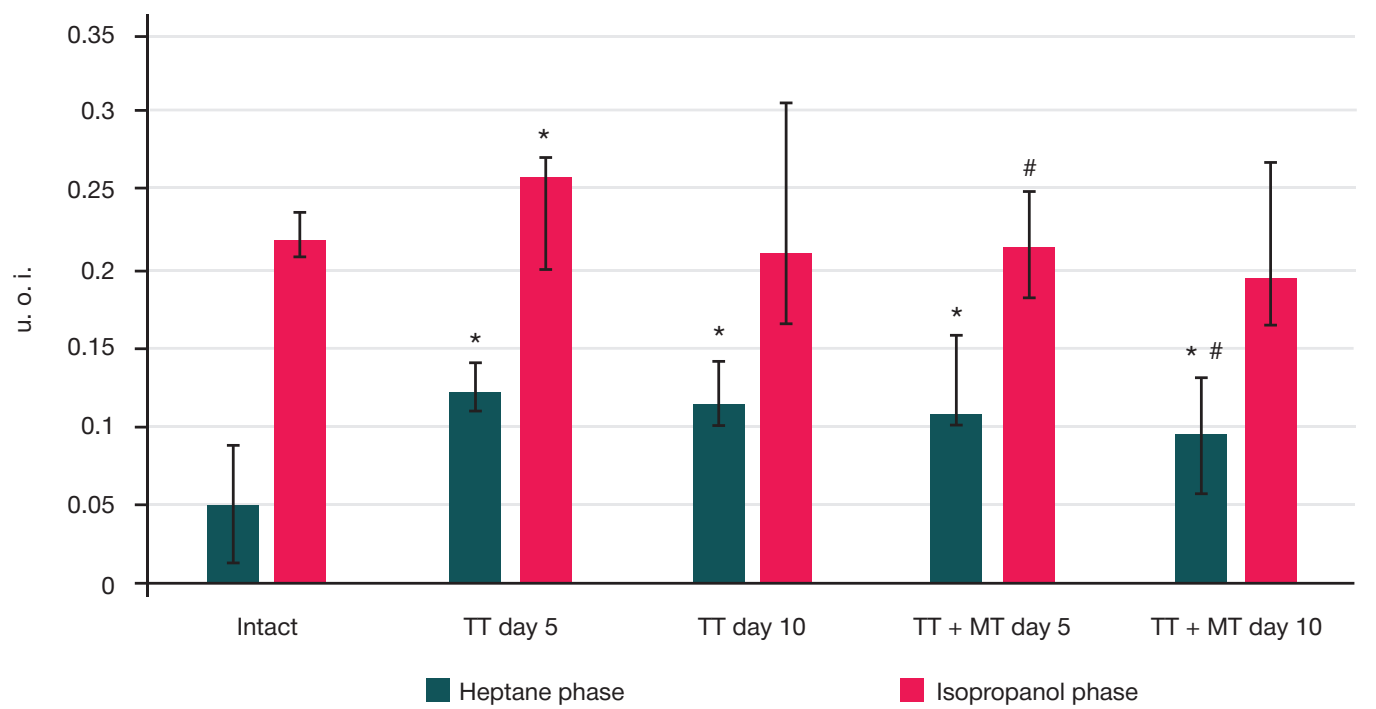

Fig. 1. Effect of MT as part of DF on the content of ketodienes and conjugated trienes in the heptane and isopropanol phases of skin homogenate, experimental TT $\left(\mathrm{Me}\left(\mathrm{Q}_{25} ; \mathrm{Q}_{75}\right)\right) .{ }^{*}$ — statistically significant $(p<0.05)$ differences with group 1 ; * - with group 2

the extraction-spectrophotometric method applied was described in earlier works [13]. Optical density was the parameter measured in the heptane and isopropanol phases of the lipid extract. The measurement wavelengths were $220 \mathrm{~nm}$ (content of isolated double bonds), $232 \mathrm{~nm}$ (content of diene conjugates, DC), $278 \mathrm{~nm}$ (content of ketodienes and conjugated trienes, KT and CT), $400 \mathrm{~nm}$ (Schiff bases, SB). The relative content of LPO products was expressed in units of oxidation indices (u.o.i): E232/E220 (DC), E278/E220 (KD and CT), and E400/E220 (SB). The POM products in the homogenate were determined by the reaction between protein carbonyl derivatives and 2,4-dinitrophenylhydrazine in spontaneous and metal-dependent modes, according to the Fenton reaction, with the following step being registration of aldehyde dinitrophenylhydrazones (ADNPH) and ketondinitrophenylhydrazones (KDNPH) in UV and visible parts of the spectrum [14]. The results were expressed in optical density units per $1 \mathrm{mg}$ of protein (c.u./mg) or in relative values (\%). The reserve adaptive potential (RAP, \%) was calculated as the ratio of difference between the total content of POM products in the induced and spontaneous modes to the content of POM products in the metal-dependent mode. IBM SPSS Statistics 19 software (SPSS: An IBM Company; USA) was used for statistical processing of the data. The indicators were presented as median $(\mathrm{Me})$ and quartiles $\left(Q_{1} ; Q_{3}\right)$. Kruskell-Wallis, Mann-Whitney, Wald-Wolfowitz tests enabled assessment of significance of differences between the groups. Spearman's correlation coefficient (R) allowed identification of relationship between the studied parameters. The differences were considered significant at $p<0.05$.

\section{RESULTS}

Assessment of the burn wound healing parameters revealed that its absolute and relative areas decreased, with the result of this decrease greater on the $10^{\text {th }}$ day compared to the 5th day. This process boosts the monitored indicators, i.e. wound epithelialization rate and proportion of decrease of its area (Table 1). On the $5^{\text {th }}$ and $10^{\text {th }}$ days, the content of LPO products registered in the wound skin homogenate changed (Fig. 1, 2). Thus, on the $5^{\text {th }}$ day the content of ketodienes, conjugated trienes and Schiff bases increased significantly in the heptane and isopropanol phases. It is predominantly reserve lipids (triacylglycerides) that accumulate in the heptane phase, while those accumulating in the isopropanol phase are membrane phospholipids. Assessment of the LPO product

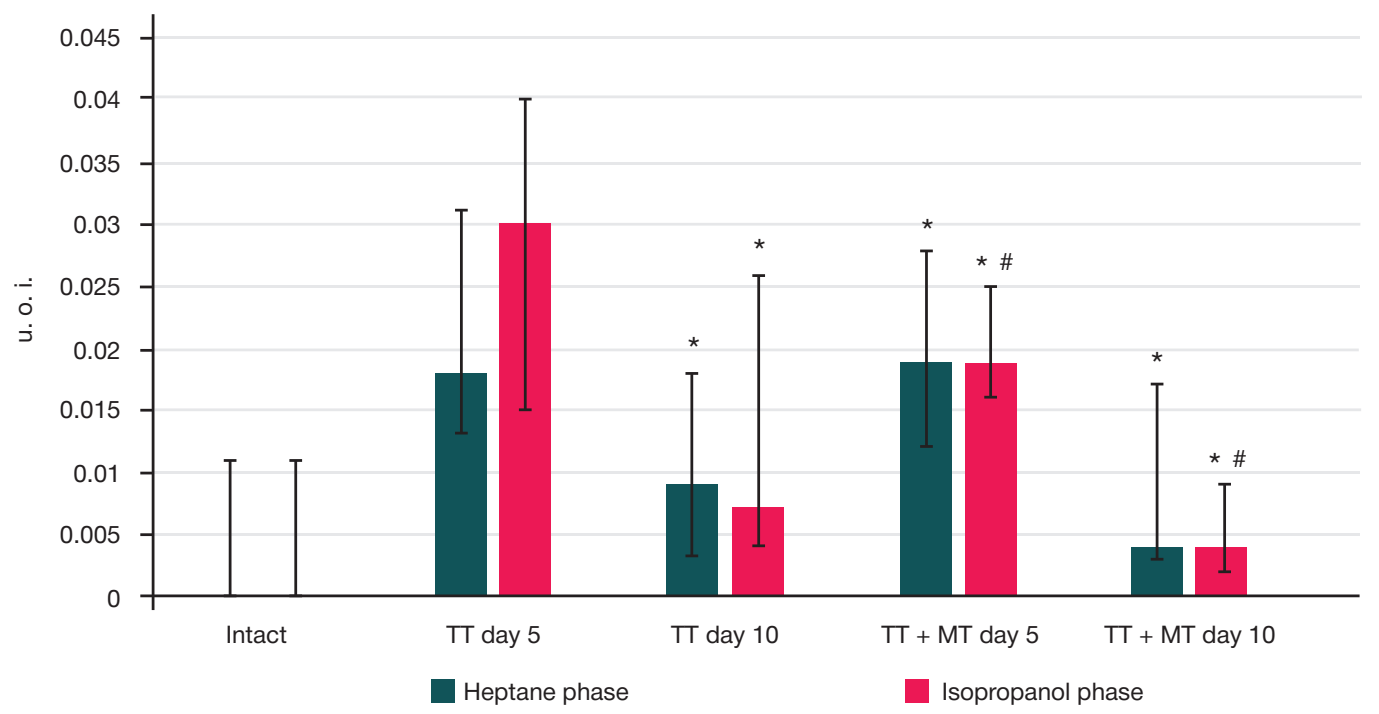

Fig. 2. Effect of $M T$ as part of DF on the content of Schiff bases in the heptane and isopropanol phases of skin homogenate, experimental $\Pi\left(M e\left(Q_{25}\right.\right.$; $\left.\left.Q_{75}\right)\right)$. ${ }^{\star}-$ statistically significant $(p<0.05)$ differences with group $1 ;{ }^{*}$ - with group 2 


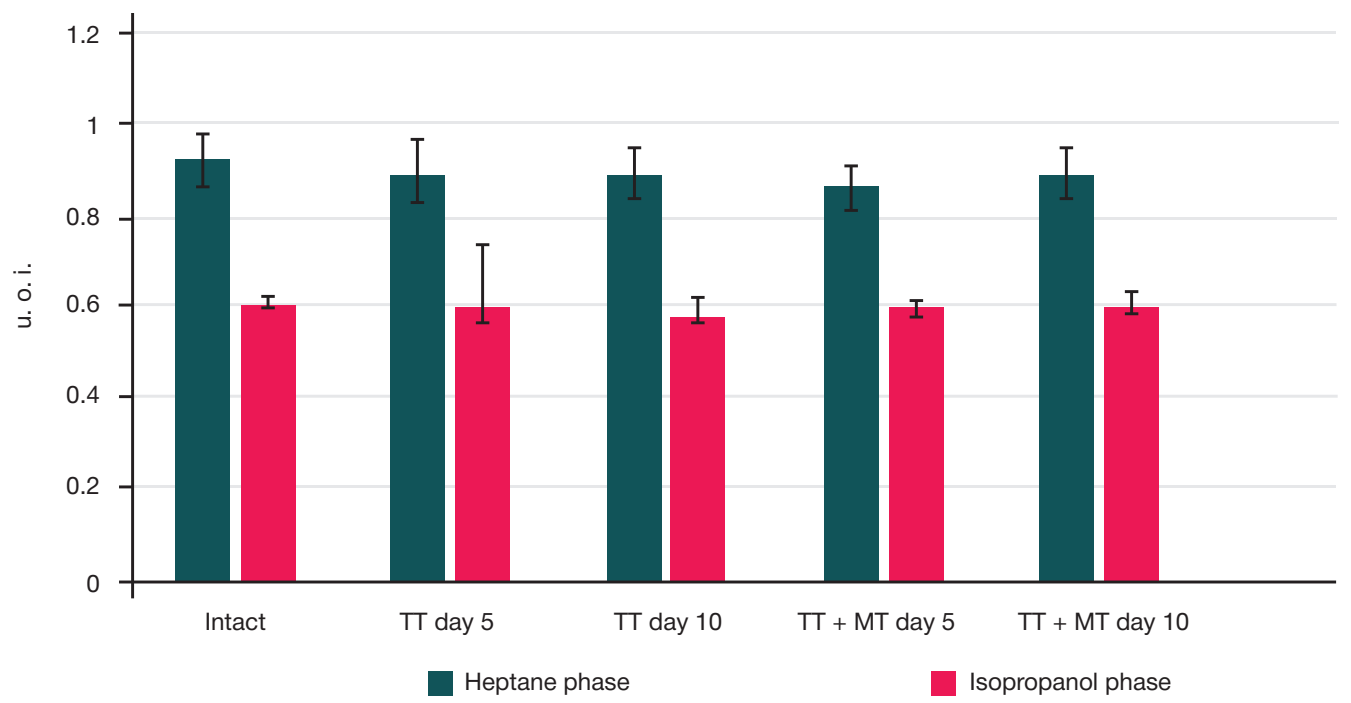

Fig. 3. Effect of MT as part of DF on the content of diene conjugates in the heptane and isopropanol phases of skin homogenate, experimental $\pi T\left(M e\left(Q_{25} ; Q_{75}\right)\right)$ content on the 10th day of $\Pi$ revealed a significant increase in ketodienes and conjugated trienes and Schiff bases in the lipid extract's heptane phase, while in the isopropanol phase only the Schiff bases have grown. As for the primary LPO products (diene conjugates), their content in the heptane and isopropanol phases of the burn wound skin homogenate's lipid did not change significantly by the $5^{\text {th }}$ and $10^{\text {th }}$ days (Fig. 2). With $\Pi T$ changing over time, the content of LPO products in the burn wound decreases: on the $10^{\text {th }}$ day, as compared with the 5 th day, the share of Schiff bases was smaller in the lipid extract's heptane phase $(p<0.01)$, and in the isopropanol phase $(p<0.01)$ the content of ketodienes, conjugated trienes and Schiff bases went down.

Table 2 shows the results of examination of POM products in the burn wound skin homogenate. The total amount of POM products increased on the 5th and 10th days of the experiment. Considered in the context of $\Pi \pi$ dynamics, the total content of POM products increased on the $10^{\text {th }}$ day in comparison with that registered on the $5^{\text {th }}$ day $(p<0.01)$. Analysis of POM components in the spontaneous mode burn wound skin homogenate revealed that on the 5th day the share of ADNPH increased significantly in the UV part of the spectrum, which is also true for the total ADNPH content and the overall amount of POM products. As for $\mathrm{KDNPH}$, their content did not change significantly in the burn skin wound homogenate on the $5^{\text {th }}$ day (as verified in both UV and visible part of the spectrum). On the $10^{\text {th }}$ day of $\Pi$ existence, there were registered ambiguous changes in the shares of various OMP products: the amount of $\mathrm{ADNPH}$ and $\mathrm{KDNPH}$ as seen in the UV part of the spectrum have grown, while that in the visible part of the spectrum has decreased significantly. Accordingly, on the $10^{\text {th }}$ day the total content of ADNPH and KDNPH has increased, as did the total content of POM products in the UV part of the spectrum, and the total content of $\mathrm{POM}$ products in the visible part of the spectrum has gone down. It should also be noted that the total content of POM products in the visible part of the spectrum on the 10th day is significantly $(p<0.01)$ higher than that on the $5^{\text {th }}$ day.

RAP of the burn wound skin homogenate was assessed through calculation of the difference between the content of POM products in the metal-induced and spontaneous modes and its share in the content of POM products in the metalinduced mode (see Table 2). This stage required studying the content of POM products in the burn wound skin homogenate after induction of protein oxidation by the components of

reaction mixture containing $\mathrm{Fe}^{2+}$ and $\mathrm{H}_{2} \mathrm{O}_{2}$, with the reaction also yielding formation of a highly reactive radical $\mathrm{OH}$ - in the Fenton reaction. The approach allows estimation of uplift in carbonyl derivatives in vitro, as influenced by the Fenton's reagent, and calculation of the ratio of results of measurement of spontaneous oxidation and induced oxidation. It was found that on the $5^{\text {th }}$ and $10^{\text {th }}$ days, POM indicators in the burn wound skin homogenate (metal-induced mode) have grown in relation to the total content of POM products, content of ADNPH and $\mathrm{KDNPH}$, with the assessment carried out for both UV and visible parts of the spectrum. In addition, the total content of ADNPH and KDNPH in the UV and visible spectra, as well as the total content of POM products therein, have increased. The changes in POM indicators peculiar to the metal-induced mode largely align with the POM indicator changes registered for the spontaneous mode on the $5^{\text {th }}$ day. With the exception of POM products in the visible part of the spectrum, same is true for the $10^{\text {th }}$ day of $\Pi$ existence. The total RAP, assessed by the total content of POM products, increased significantly on the $5^{\text {th }}$ day and did not change on the $10^{\text {th }}$ day. The change of the $5^{\text {th }}$ day results from the RAP's growth in relation to ADNPH and $\mathrm{KDNPH}$ in the UV and visible spectra, with ADNPH growing predominantly in the visible part of the spectrum, and KDNPH in both UV and visible spectra. On the 10th day, the overall RAP was significantly $(p<0.01)$ lower than on the 5 th day of the experiment.

It was established that, in absolute figures, application of DF with MT to a TT wound decreases the burn wound significantly on the $5^{\text {th }}$ and $10^{\text {th }}$ days, and in relative values - on the $10^{\text {th }}$ day (see Table 1). The wound epithelialization rate and the relative wound area shrinking process accelerated on the 5th and $10^{\text {th }}$ days of observation. On the $5^{\text {th }}$ day of $T$ existence, the absolute area of the burn surface decreased by $11 \%$ (median). The maximum change was recorded on the $10^{\text {th }}$ day, when the absolute area of the wound decreased by $12 \%$ and the epithelialization rate have grown by $246 \%$ (median) relative to the group that had no DF with MT applied after TT infliction. Dynamics of experimental $T T$ have shown that on the $10^{\text {th }}$ day, as compared to the $5^{\text {th }}$ day, the burn area has decreased significantly $(p<0.01)$, and the rate of wound epithelialization and relative wound area shrinkage have increased. As shown in Table 2, we have registered changes in LPO products content in the burn wound skin homogenate's lipid extract in the group that had DF with MT applied to the TT (see Table 2). On the $5^{\text {th }}$ day of observation, the content of ketodienes and 
Table 2. Effect of MT as part of DF on the content of POM products in skin homogenate, with experimental $T\left(M e\left(Q_{25} ; Q_{75}\right)\right)$

\begin{tabular}{|c|c|c|c|c|c|}
\hline Indicators & $\begin{array}{l}\text { Group } 1 \\
\text { Intact } \\
(n=20)\end{array}$ & $\begin{array}{l}\text { Group } 2 \\
T T, 5^{\text {th }} \text { day } \\
(n=16)\end{array}$ & $\begin{array}{c}\text { Group } 2 \\
\text { TT, } 10^{\text {th }} \text { day } \\
(n=20)\end{array}$ & $\begin{array}{c}\text { Group } 3 \\
\mathrm{TT}+\mathrm{MT}^{\text {th }} \text { day } \\
(n=16)\end{array}$ & $\begin{array}{c}\text { Group } 3 \\
\mathrm{TT}+\mathrm{MT} 10^{\text {th }} \text { day } \\
(n=16)\end{array}$ \\
\hline$S_{\text {ADNPH }}$ uv (sp), c.u./mg & $\begin{array}{c}29.85 \\
(24.69 ; 32.84)\end{array}$ & $\begin{array}{c}51.49 \\
(48.03 ; 55.81)^{\star}\end{array}$ & $\begin{array}{c}60.50 \\
(52.95 ; 93.13)^{\star}\end{array}$ & $\begin{array}{c}32.87 \\
(31.04 ; 48.35)^{\#}\end{array}$ & $\begin{array}{c}53.71 \\
(45.11 ; 59.16)^{\star \#}\end{array}$ \\
\hline$S_{\text {ADNPH }}$ vs (sp), c.u./mg & $\begin{array}{c}6.93 \\
(5.32 ; 8.71)\end{array}$ & $\begin{array}{c}6.91 \\
(5.72 ; 9.75)\end{array}$ & $\begin{array}{c}3.53 \\
(2.09 ; 5.07)^{\star}\end{array}$ & $\begin{array}{c}7.09 \\
(5.17 ; 12.27)\end{array}$ & $\begin{array}{c}5.24 \\
(3.10 ; 7.17)^{\star \#}\end{array}$ \\
\hline$S_{\text {KDNFH }}$ uv (sp), c.u./mg & $\begin{array}{c}8.19 \\
(7.37 ; 10.59)\end{array}$ & $\begin{array}{c}7.79 \\
(7.34 ; 9.43)\end{array}$ & $\begin{array}{c}15.19 \\
(9.05 ; 25.63)^{\star}\end{array}$ & $\begin{array}{c}9.29 \\
(7.56 ; 16.39)\end{array}$ & $\begin{array}{c}8.22 \\
(6.48 ; 12.61)^{\#}\end{array}$ \\
\hline$S_{\text {KDNFH }}$ vs (sp), c.u./mg & $\begin{array}{c}0.89 \\
(0.69 ; 1.14)\end{array}$ & $\begin{array}{c}0.91 \\
(0.69 ; 1.41)\end{array}$ & $\begin{array}{c}0.50 \\
(0.35 ; 0.66)^{*}\end{array}$ & $\begin{array}{c}0.79 \\
(0.66 ; 1.42)\end{array}$ & $\begin{array}{c}0.45 \\
(0.27 ; 0.77)\end{array}$ \\
\hline S POM (sp), c.u./mg & $\begin{array}{c}47.83 \\
(41.94 ; 55.40)\end{array}$ & $\begin{array}{c}66.87 \\
(60.56 ; 76.11)^{\star}\end{array}$ & $\begin{array}{c}79.30 \\
(62.59 ; 122.34)^{\star}\end{array}$ & $\begin{array}{c}49.97 \\
(41.94 ; 79.07)^{\#}\end{array}$ & $\begin{array}{c}64.65 \\
(56.91 ; 76.64)^{\star \#}\end{array}$ \\
\hline $\mathrm{S}_{\text {ADNFH }}(\mathrm{sp})$, c.u. $/ \mathrm{mg}$ & $\begin{array}{c}38.54 \\
(30.64 ; 41.39)\end{array}$ & $\begin{array}{c}59.19 \\
(52.29 ; 62.31)^{\star}\end{array}$ & $\begin{array}{c}65.04 \\
(54.51 ; 96.45)^{\star}\end{array}$ & $\begin{array}{c}40.77 \\
(35.11 ; 64.89)^{\#}\end{array}$ & $\begin{array}{c}57.90 \\
(48.93 ; 64.39)^{\text {*\# }}\end{array}$ \\
\hline$S_{\text {KDNFH }}(\mathrm{sp})$, c.u. $/ \mathrm{mg}$ & $\begin{array}{c}10.12 \\
(8.23 ; 11.31)\end{array}$ & $\begin{array}{c}8.81 \\
(8.09 ; 10.67)\end{array}$ & $\begin{array}{c}15.49 \\
(9.56 ; 26.11)^{\star}\end{array}$ & $\begin{array}{c}10.28 \\
(8.23 ; 18.01)\end{array}$ & $\begin{array}{c}8.97 \\
(6.76 ; 13.15)^{\#}\end{array}$ \\
\hline S uv (sp), c.u./mg & $\begin{array}{c}38.47 \\
(34.05 ; 45.31)\end{array}$ & $\begin{array}{c}59.10 \\
(53.57 ; 68.66)^{\star}\end{array}$ & $\begin{array}{c}74.97 \\
(60.81 ; 118.45)^{\star}\end{array}$ & $\begin{array}{c}40.94 \\
(36.99 ; 64.74)^{\#}\end{array}$ & $\begin{array}{c}61.28 \\
(52.69 ; 70.97)^{\star \#}\end{array}$ \\
\hline S vs (sp), c.u./mg & $\begin{array}{c}7.87 \\
(6.02 ; 9.73)\end{array}$ & $\begin{array}{c}7.81 \\
(6.41 ; 11.16)\end{array}$ & $\begin{array}{c}4.05 \\
(2.35 ; 5.85)^{\star}\end{array}$ & $\begin{array}{c}7.88 \\
(5.84 ; 13.69)\end{array}$ & $\begin{array}{c}5.67 \\
(3.37 ; 7.89)^{\#}\end{array}$ \\
\hline$S_{\text {ADNFH }}$ uv (ind), c.u./mg & $\begin{array}{c}90.68 \\
(70.81 ; 94.67)\end{array}$ & $\begin{array}{c}386.82 \\
(279.79 ; 542.03)^{\star}\end{array}$ & $\begin{array}{c}178.71 \\
(128.45 ; 239.17)^{\star}\end{array}$ & $\begin{array}{c}260.81 \\
(94.29 ; 50.90)^{\star \#}\end{array}$ & $\begin{array}{c}211.60 \\
(140.76 ; 235.78)^{\star}\end{array}$ \\
\hline$S_{\text {ADNFH }}$ vs (ind), c.u./mg & $\begin{array}{c}18.81 \\
(16.01 ; 21.09)\end{array}$ & $\begin{array}{c}156.21 \\
(90.34 ; 244.15)^{\star}\end{array}$ & $\begin{array}{c}37.79 \\
(29.25 ; 60.75)^{*}\end{array}$ & $\begin{array}{c}91.49 \\
(19.62 ; 264.02)^{\star \#}\end{array}$ & $\begin{array}{c}68.35 \\
(45.15 ; 100.18)^{\star \#}\end{array}$ \\
\hline $\mathrm{S}_{\mathrm{KDNFH}} \mathrm{uv}$ (ind), c.u./mg & $\begin{array}{c}28.73 \\
(24.72 ; 37.55)\end{array}$ & $\begin{array}{c}208.12 \\
(128.85 ; 320.23)^{\star}\end{array}$ & $\begin{array}{c}76.51 \\
(45.82 ; 94.77)^{\star}\end{array}$ & $\begin{array}{c}125.89 \\
(29.35 ; 333.99)^{\star \#}\end{array}$ & $\begin{array}{c}93.56 \\
(60.57 ; 127.56)^{\star \#}\end{array}$ \\
\hline$S_{\mathrm{KDNFH}}$ vs (ind), c.u./mg & $\begin{array}{c}2.07 \\
(1.62 ; 2.32)\end{array}$ & $\begin{array}{c}14.53 \\
(8.45 ; 22.58)^{\star}\end{array}$ & $\begin{array}{c}3.84 \\
(2.93 ; 6.02)^{*}\end{array}$ & $\begin{array}{c}8.84 \\
(2.32 ; 26.09)^{\star \#}\end{array}$ & $\begin{array}{c}6.61 \\
(4.68 ; 9.76)^{\star \#}\end{array}$ \\
\hline S POM (ind), c.u./mg & $\begin{array}{c}140.38 \\
(113.93 ; 155.46)\end{array}$ & $\begin{array}{c}771.61 \\
(507.38 ; 1128.99)^{\star}\end{array}$ & $\begin{array}{c}312.84 \\
(207.79 ; 393.90)^{\star}\end{array}$ & $\begin{array}{c}487.04 \\
(145.58 ; 1175.01)^{\star \#}\end{array}$ & $\begin{array}{c}378.89 \\
(262.70 ; 476.87)^{\star \#}\end{array}$ \\
\hline$S_{\text {ADNFH }}$ (ind), c.u./mg & $\begin{array}{c}109.49 \\
(87.20 ; 115.77)\end{array}$ & $\begin{array}{c}548.02 \\
(370.12 ; 786.18)^{\star}\end{array}$ & $\begin{array}{c}230.51 \\
(157.87 ; 301.83)^{\star}\end{array}$ & $\begin{array}{c}352.30 \\
(113.90 ; 814.93)^{\star \#}\end{array}$ & $\begin{array}{c}277.53 \\
(197.90 ; 338.84)^{\star}\end{array}$ \\
\hline$S_{\mathrm{KDNFH}}$ (ind), c.u./mg & $\begin{array}{c}30.82 \\
(26.73 ; 39.69)\end{array}$ & $\begin{array}{c}223.59 \\
(137.26 ; 342.81)^{\star}\end{array}$ & $\begin{array}{c}80.12 \\
(48.56 ; 101.26)^{\star}\end{array}$ & $\begin{array}{c}134.74 \\
(31.67 ; 360.08)^{\star}\end{array}$ & $\begin{array}{c}99.88 \\
(64.40 ; 138.03)^{\star \#}\end{array}$ \\
\hline S uv (ind), c.u./mg & $\begin{array}{c}119.47 \\
(95.53 ; 132.23)\end{array}$ & $\begin{array}{c}594.94 \\
(408.64 ; 862.26)^{\star}\end{array}$ & $\begin{array}{c}252.79 \\
(175.39 ; 344.84)^{\star}\end{array}$ & $\begin{array}{c}386.71 \\
(123.64 ; 884.89)^{\star \#}\end{array}$ & $\begin{array}{c}304.79 \\
(218.89 ; 363.53)^{\star \#}\end{array}$ \\
\hline S vs (ind), c.u./mg & $\begin{array}{c}20.91 \\
(17.63 ; 23.23)\end{array}$ & $\begin{array}{c}170.73 \\
(98.74 ; 266.73)^{\star}\end{array}$ & $\begin{array}{c}41.63 \\
(32.13 ; 66.99)^{*}\end{array}$ & $\begin{array}{c}100.33 \\
(21.94 ; 290.12)^{* \#}\end{array}$ & $\begin{array}{c}74.96 \\
(49.83 ; 109.94)^{\star \#}\end{array}$ \\
\hline RAP, \% & $\begin{array}{c}61.81 \\
(53.98 ; 72.55)\end{array}$ & $\begin{array}{c}91.66 \\
(86.44 ; 94.78)^{\star}\end{array}$ & $\begin{array}{c}69.22 \\
(62.76 ; 74.76)\end{array}$ & $\begin{array}{c}83.77 \\
(71.19 ; 96.33)^{\star}\end{array}$ & $\begin{array}{c}81.15 \\
(74.35 ; 86.09)^{\star \#}\end{array}$ \\
\hline
\end{tabular}

Note: * — statistically significant $(p<0.05)$ differences with group 1 ; ${ }^{*}$ - with group 2.

conjugated trienes, as well as Schiff bases, in the isopropanol phase of the lipid extract has decreased significantly. As for the content of diene conjugates, ketodienes and conjugated trienes, as well as Schiff bases in the heptane phase, and Schiff bases in the isopropanol phase of the lipid extract, these did not differ significantly from the same indicators registered in the group of animals that had $T \mathrm{~T}$ inflicted but no DF with MT applied. On the $10^{\text {th }}$ day of the experiment, we have identified a significant decrease in ketodienes and conjugated trienes in the heptane phase, Schiff bases in the isopropanol phase of the burn wound skin homogenate's lipid extract. The data obtained indicate that the effect MT produces on TT as part of DF is maximal in the isopropanol phase of the burn wound skin homogenate's lipid extract. As for the content of secondary and end LPO products in the heptane and isopropanol phases, it was lower on the $10^{\text {th }}$ day $(p<0.01)$ than on the $5^{\text {th }}$ day of $T$ evolution, which is same as registered in the group that did not receive DF with MT.

The use of MT in the composition of DF applied to TT leads to a change in the content of POM products in the burn wound (see Table 2). On the $5^{\text {th }}$ day of the experiment, in the spontaneous mode, the content of ADNPH in UV spectrum, the total content of $\mathrm{ADNPH}$, the total content of POM products in UV spectrum have decreased; consequently, the total content of POM products has grown down. It should be noted that the values of these indicators do not differ from the values captured in the group of intact animals, which allows stating their complete recovery. On the $10^{\text {th }}$ day, in the spontaneous mode, the total content of POM products seen in the $\Pi T$ groups has decreased and did match the values peculiar to the group of intact animals, i.e. the recovery was only partial. Against this background, the content of ADNPH and KDNPH in the UV region, the total content of $\mathrm{ADNPH}$ and $\mathrm{KDNPH}$, POM products in the UV region have decreased and completely recovered in relation to KDNPH in the UV region, and POM products in the UV region. When assessing the RAP, its decrease on the 5th day was found to depend on the approximately equivalent contribution of the studied primary and secondary POM products in the visible and UV light range. On the $10^{\text {th }}$ day, RAP 
Table 3. Correlation between burn area $\left(\mathrm{cm}^{2}\right)$ and FRO indicators in the skin homogenate, experimental TT, application of DF with MT

\begin{tabular}{|l|l|l|}
\hline \multicolumn{1}{|c|}{ Indicators } & $5^{\text {th }}$ day & $10^{\text {th }}$ day \\
\hline DC (heptane phase), u.o.i & $\mathrm{R}=0.21$ & $\mathrm{R}=0.18$ \\
\hline KD and CT (heptane phase), u.o.i. & $\mathrm{R}=0.34$ & $\mathrm{R}=0.52$ \\
\hline $\mathrm{SB}$ (heptane phase), u.o.i & $\mathrm{R}=0.17$ & $\mathrm{R}=0.27$ \\
\hline DC (isopropanol phase), u.o.i. & $\mathrm{R}=0.17$ & $\mathrm{R}=0.15$ \\
\hline KD and CT (isopropanol phase), u.o.i. & $\mathrm{R}=0.68$ & $\mathrm{R}=0.21$ \\
\hline SB (heptane phase), u.o.i & $\mathrm{R}=0.53$ & $\mathrm{R}=0.51$ \\
\hline S POM (spont. mode), c.u./mg & $\mathrm{R}=0.74$ & $\mathrm{R}=0.67$ \\
\hline S POM (ind. mode), c.u./mg & $\mathrm{R}=0.53$ & $\mathrm{R}=-0.25$ \\
\hline S ADNPH (spont. mode), c.u./mg protein & $\mathrm{R}=0.51$ & $\mathrm{R}=0.39$ \\
\hline S KDNFH (spont. mode), c.u./mg protein & $\mathrm{R}=0.07$ & $\mathrm{R}=0.47$ \\
\hline S uv (spont. mode), c.u./mg protein & $\mathrm{R}=0.57$ & $\mathrm{R}=0.37$ \\
\hline S vs (spont. mode), c.u./mg protein & $\mathrm{R}=0.18$ & $\mathrm{R}=0.51$ \\
\hline
\end{tabular}

Note: significant $(p<0.05)$ connections are highlighted in bold.

has increased in the DF with MT group, mainly driven by the RAP growing in relation to ADNPH and $\mathrm{KDNPH}$ in the visible spectrum, KDNPH in the UV spectrum.

\section{DISCUSSION}

We found that in the locus of thermal damage to the skin, the amount of secondary and end LPO products increases in the heptane and isopropanol phases of lipid extract. With $\Pi$, the total amount of carbonyl derivatives of proteins goes up, and they are irreversible products of oxidative stress formed due to the oxidation of several amino acid residues, as well as interactions with LPO products and reducing sugars. Since neutral carbonyl derivatives accumulate in the UV spectrum, and basic carbonyl derivatives accumulate in the visible part of the range, a relative analysis of the total content of carbonyls in the UV and visible spectra allows assessment of the nature of the products formed against the background of $\Pi \pi$ dynamics. On the $5^{\text {th }}$ and $10^{\text {th }}$ days of $\Pi$ existence, the POM products accumulating predominantly are neutral, as evidenced by an increase in the total amount of products in the UV region of the spectrum. In the $\Pi$ groups, the total ADNPH content in the skin increases on the $5^{\text {th }}$ and $10^{\text {th }}$ days, that of $\mathrm{KDNPH}$ - on the $10^{\text {th }}$ day. This fact allows registering primary POM products accumulation on the $5^{\text {th }}$ and $10^{\text {th }}$ days, these products being the early markers of oxidative protein destruction, with another phenomenon registered being predominant aggregation of proteins under the influence of $\mathrm{OH}$. On the $10^{\text {th }}$ day, it is the secondary POM products that accumulate, which are late markers of oxidative protein destruction, and the second phenomenon registered is predominant fragmentation of proteins under the influence of the combined action of $\mathrm{OH}^{-}$and $\mathrm{O}_{2}{ }^{-}$radicals. Protein fragments are highly resistant to proteolysis, have toxic properties and can initiate apoptosis or cell necrosis, expanding the zone of secondary alteration. Skin is the largest organ with intensive $\mathrm{LPO}$ and POM processes, and the LPO and POM products formed therein can have a local and distant cytotoxic effect [15]. Oxidative stress in burns is registered not only in the locus, but also in the heart, lungs, kidneys and other organs, where protein, lipid and DNA damage products are found [16]. The main inducers of oxidative stress after $\Pi$ are activated neutrophils, monocytes/macrophages, endotheliocytes with known systems for generating reactive oxygen species (ROS): NADPH oxidase and MPO, xanthine oxidase, NO synthase [17]. Increased production of endogenous glucocorticoids plays an important part in escalation of oxidative stress in the presence of $\Pi$ [18]. The depletion of the antioxidant defense system contributes to the pathogenesis of oxidative stress with $\Pi \mathrm{T}$ - the content of reduced glutathione, activity of SOD, catalase, and glutathione peroxidase (GPO) decrease [19]. We demonstrated a decrease in the body levels of zinc and copper, which are part of SOD, due to their loss with urine and burn wound exudate, as well as a deficiency of selenium, HPO component, due to a decrease in the intake through the gastrointestinal tract associated with burns [20]. We also demonstrated the role of iron in the activation of oxidative metabolism in the presence of $T$. ROS in a burn wound are associated not only with tissue destruction and negative consequences: they also participate in activation of the pro-matrix metalloproteinase and skin repair after $\Pi$ [21]. ROS play an important role in the modification of components of the extracellular matrix of connective tissue - glycosaminoglycans, collagens, and noncollagen glycoproteins. Also, they contribute to wound healing through activation of signaling pathways in stem cells [22]. ROS generated during inflammation associated with $\Pi$ induce local synthesis of pro- and anti-inflammatory cytokines.

According to the results of the study, the use of MT in the composition of the DF applied to a TT injury accelerates healing of the burn wound, reduces its area and reduces the content of oxidative stress metabolites - LPO and POM products. On the $5^{\text {th }}$ day of $T T$ existence, the content of secondary and end LPO products in the lipid fraction of phospholipids decreases; on the 10th day, the content of secondary LPO products in the lipid fraction of triglycerides and end LPO products in the phospholipid fraction decrease. MT limits POM: on the 5th, this process relies on the neutral amino acid residues of the primary POM products and on the protein fragmentation decrease, on the $10^{\text {th }}$ day it relies on the neutral amino acid residues of primary and secondary POM products and a decrease in protein fragmentation and aggregation. We believe there is a number of mechanisms that drive the decrease of content of LPO and POM products in a burn wound with experimental $\Pi \mathrm{T}$ after application of DF with MT. MT can be rapidly distribute inside the cell and in the intercellular fluid through passive diffusion, as well as with the help of glucose transporters (GLUT1) and oligopeptides (PEPT1/2) [23, 24]. MT1 receptor is found in keratinocytes and fibroblasts of the skin, hair follicle cells; MT2 receptor is found mainly in the eccrine glands and blood vessels of the skin, melanocytes; $\mathrm{ROR} \alpha$ nuclear receptor for MT was identified in keratinocytes, fibroblasts, melanocytes [25-27]. In the skin, MT can absorb $\mathrm{ROS}\left(\mathrm{OH}, \mathrm{H}_{2} \mathrm{O}_{2}\right)$ directly, and one MT molecule is capable of 
binding up to four or more ROS. MT's antioxidant effect is more pronounced than that of an equivalent dose of vitamins $C$ and $E$ [28]. There is also indirect antioxidant effect, which is the result of an increase in glutathione synthesis, activation of glutathione peroxidase, glutathione reductase, glutathione-S-transferase, SOD, catalase, hemoxidase-1, and a decrease in the activity of quinone reductase-2, NOS-1 [29]. Moreover, MT realizes its antioxidant effect by maintaining the mitochondrial membrane potential and increasing oxidative phosphorylation, production of ATP and not ROS [30]. Apparently, the antioxidant effect of MT in the $\Pi$ locus, lighter damage to proteins and lipids that make up cytoplasmic membranes and cell organelles limit secondary alteration, reduce the term of vascular and exudative reactions, help activate reparative reactions earlier and reduce healing time of a burn wound. Correlation analysis of the burn surface area and content of LPO and POM products in the $\Pi$ locus with DF with MT applied (Table 3) has shown that on the 5th day of $T T$ existence there is direct average strength connection between the absolute area of the burn and content of secondary and end LPO products in lipid extract's isopropanol phase in the burn wound, as well as weak connection with the content of secondary LPO products in the heptane phase, direct average strength connection with the total content of POM products in spontaneous and induced modes, and the total content of primary POM products and the total content of neutral POM products. On the $10^{\text {th }}$ day of $\Pi$ existence, there was established a direct average strength connection between the content of secondary LPO products in the heptane phase and end POM products in the isopropanol phase of the lipid extract, total content of basic POM products, content of POM products in spontaneous mode, a weak direct connection with total content of primary and secondary POM products, neutral POM products in spontaneous mode.

\section{CONCLUSION}

The study allowed achieving the goal set and establishing that with the evolution of $\pi$, a burn wound sees growth of content of secondary and end LPO products in heptane and isopropanol phases of the lipid extract, same as the content of predominantly neutral primary and secondary POM products. It was demonstrated that application of DF with MT (original composition) to $\Pi T$ reduces absolute and relative areas of the burn, boosts wound epithelialization, and reduces the content of LPO and OMP products in the burn wound. When TT has DF with MT applied to it, the area of the burn is associated with the content of LPO products and OMP products in the burn wound. The results obtained expand the existing understanding of the role of redox status changes in $\Pi$ pathogenesis, serve as a prerequisite for further studies of FRO in the skin of admitted patients with burns (clinical studies) in order to designate LPO and OMP products as diagnostic markers and predictors of complications, as well as indicators the effectiveness of therapy. The antioxidant and reparation stimulating effect of $M T$ as part of DF, which we have demonstrated at the preclinical stage, is a prerequisite for further study of the action mechanism and the effectiveness of MT application in clinical settings.

\section{References}

1. Statisticheskij sbornik 2018 god. Social'no-znachimye zabolevanija naselenija Rossii $\vee 2018$ godu. 2019; 11: 69. Dostupno po ssylke: https://www.rosminzdrav.ru/ministry/61/22/stranitsa-979/ statisticheskie-i-informatsionnye-materialy/statisticheskiy-sbornik2018-god. Russian.

2. Li H, Yao Z, Tan J, et al. Epidemiology and outcome analysis of 6325 burn patients: a five-year retrospective study in a major burn center in Southwest China. Sci Rep. 2017; 7: 46066. DOI: 10.1038/srep46066.

3. Abdullahi A, Jeschke MG. Taming the Flames: Targeting White Adipose Tissue Browning in Hypermetabolic Conditions. Endocrine Reviews. 2017; 38 (6): 538-49.

4. Geqgotek A, Skrzydlewska E. Biological effect of protein modifications by lipid peroxidation products. Chemistry and Physics of Lipids. 2019; 221: 46-52. DOI: 10.1016/j. chemphyslip.2019.03.011.

5. Valacchi G, Virgili F, Cervellati C, Pecorelli A. OxInflammation: From Subclinical Condition to Pathological Biomarker. Front Physiol. 2018; 9: 858. DOI: 10.3389/fphys.2018.00858.

6. Hawkins CL, Davies MJ. Detection, identification, and quantification of oxidative protein modifications. Journal of Biological Chemistry. 2019; 294 (51): 19683-708.

7. Murray RZ, West ZE, Cowin AJ, Farrugia BL. Development and use of biomaterials as wound healing therapies. Burns Trauma. 2019; 7: 2. DOl: 10.1186/s41038-018-0139-7.

8. Osikov MV. Vlijanie jeritropojetina na processy svobodnoradikal'nogo okislenija i jekspressiju glikoproteinov v trombocitah pri hronicheskoj pochechnoj nedostatochnosti. Bjulleten' jeksperimental'noj biologii i mediciny. 2014; 157 (1): 30-33. Russian.

9. Osikov MV, Telesheva LF, Ageev Yul. Vlijanie jeritropojetina na apoptoz limfocitov pri jeksperimental'noj hronicheskoj pochechnoj nedostatochnosti. Bjulleten' jeksperimental'noj biologii i mediciny. 2015; 3: 326-9. Russian.
10. Osikov MV. Rol' orozomukoida v reguljacii aktivnosti sistem plazmennogo proteoliza pri jeksperimental'noj pochechnoj nedostatochnosti. Bjulleten' jeksperimental'noj biologii i mediciny. 2009; 7: 27-30. Russian.

11. Osikov MV, Telesheva LF, Ageev YI. Antioxidant effect of erythropoietin during experimental chronic renal failure. Bulletin of Experimental Biology and Medicine. 2015; 160 (2): 202-4.

12. Varoni EM, Soru C, Pluchino R, Intra C, Iriti M. The Impact of Melatonin in Research. Molecules. 2016; 21 (2): 240. DOI: 10.3390/molecules21020240.

13. Volchegorskij IA, Nalimov AG, Yarovinskij VG. Sopostavlenie razlichnyh podhodov k opredeleniju produktov POL $\vee$ geptanizopropanol'nyh jekstraktah krovi. Voprosy medicinskoj himii. 1989; 35 (1): 127-31. Russian.

14. Fomina MA, Abalenihina YuV. Sposob kompleksnoj ocenki soderzhanija produktov okislitel'noj modifikacii belkov $\vee$ tkanjah i biologicheskih zhidkostjah: metodicheskie rekomendacii. GBOU VPO RjazGMU Minzdrava. Rjazan': RIO RjazGMU, 2014. Russian.

15. Mitran MI, Nicolae I, Tampa M, Mitran Cl, Caruntu C, Sarbu MI, et al. Reactive Carbonyl Species as Potential Pro-Oxidant Factors Involved in Lichen Planus Pathogenesis. Metabolites. 2019; 9 (10): E213. DOI: 10.3390/metabo9100213.

16. Wei C, Ding X, Liu C, Pei Y, Zhong Y, Sun W. Mechanism of taurine in alleviating myocardial oxidative stress in rats after burn through p38 MAPK signaling pathway. Minerva Med. 2019; 110 (5): 472-75.

17. Jacob S, Herndon DN, Hawkins HK, Enkhbaatar P, Cox RA. Xanthine oxidase contributes to sustained airway epithelial oxidative stress after scald burn. International journal of burns and trauma. 2017; 7 (6): 98-106.

18. Klein GL. The role of the musculoskeletal system in post-burn hypermetabolism. Metabolism. 2019; 97: 81-86.

19. ErginTuncay M, Erkilıc A, Gunes A, Nural C, Erel O. A remarkable point for evaluating the severity of burns: Thiol-disulfide profile. 
Burns. 2019; 46 (4): 0305-4179(19)30638-2. DOI: 10.1016/j. burns.2019.10.013.

20. Lee YH, Bang ES, Lee JH, Lee JD, Kang DR, Hong J, Lee JM Serum Concentrations of Trace Elements Zinc, Copper, Selenium, and Manganese in Critically III Patients. Biological Trace Element Research. 2019; 188 (2): 316-25.

21. Lindley LE, Stojadinovic O, Pastar I, Tomic-Canic M. Biology and Biomarkers for Wound Healing. Plastic and Reconstructive Surgery. 2016; 138 (3): 18-28.

22. Lee HJ, Jang YJ. Recent. Understandings of Biology, Prophylaxis and Treatment Strategies for Hypertrophic Scars and Keloids. International Journal of Molecular Sciences. 2018; 19 (3): 711. DOI: 10.3390/ijms19030711.

23. Yu H, Dickson EJ, Jung SR, Koh DS, Hille B. High membrane permeability for melatonin. The Journal of General Physiology. 2016; 147: 63-76.

24. Mayo JC, Aguado A, Cernuda-Cernuda R, Alvarez-Artime A, Cepas V, Quiros-Gonzalez I, et al. Melatonin uptake by cells: an answer to its relationship with glucose? Molecules. 2018; 23 e1999. DOI: 10.3390/molecules23081999.

25. Janjetovic Z, Jarrett SG, Lee EF, Duprey C, Reiter RJ, Slominski AT. Melatonin and its metabolites protect human melanocytes against UVB-induced damage: Involvement of NRF2-mediated pathways.
Scientific Reports. 2017; 7 (1): 1274. DOI: 10.1038/s41598-01701305-2.

26. Rusanova I, Martínez-Ruiz L, Florido Ja, Rodríguez-Santana C, Guerra-Librero A, Acuña-Castroviejo D, et al. Protective Effects of Melatonin on the Skin: Future Perspectives. International Journal of Molecular Sciences. 2019; 20 (19): 4948. DOI: 10.3390/ ijms20194948.

27. Dai J, Choo MK, Park JM, Fisher DE. Topical ROR inverse agonists suppress inflammation in mouse models of atopic dermatitis and acute irritant dermatitis. Journal of Investigative Dermatology. 2017; 137: 2523-31.

28. Slominski AT, Semak I, Fischer TW, Kim TK, Kleszczyński K, Hardeland R, et al. Metabolism of melatonin in the skin: Why is it important? Experimental Dermatology. 2017; 26: 563-8.

29. Janjetovic Z, Jarrett SG, Lee EF, Duprey C, Reiter RJ, Slominski AT. Melatonin and its metabolites protect human melanocytes against UVB-induced damage: Involvement of NRF2-mediated pathways. Scientific Reports. 2017; 7 (1): 1274. DOI: 10.1038/s41598-01701305-2.

30. Reiter RJ, Rosales-Corral S, Tan DX, Jou MJ, Galano A, Xu B. Melatonin as a mitochondria-targeted antioxidant: one of evolution's best ideas. Cellular and Molecular Life Sciences. 2017; 74 (21): 3863-81.

\section{Литература}

1. Статистический сборник 2018 год. Социально-значимые заболевания населения России в 2018 году. 2019; 11: 69. Доступно по ссылке: https://www.rosminzdrav.ru/ministry/61/22/ stranitsa-979/statisticheskie-i-informatsionnye-materialy/ statisticheskiy-sbornik-2018-god.

2. Li H, Yao Z, Tan J, et al. Epidemiology and outcome analysis of 6325 burn patients: a five-year retrospective study in a major burn center in Southwest China. Sci Rep. 2017; 7: 46066. DOl: 10.1038/srep46066.

3. Abdullahi A, Jeschke MG. Taming the Flames: Targeting White Adipose Tissue Browning in Hypermetabolic Conditions. Endocrine Reviews. 2017; 38 (6): 538-49.

4. Gęgotek A, Skrzydlewska E. Biological effect of protein modifications by lipid peroxidation products. Chemistry and Physics of Lipids. 2019; 221: 46-52. DOI: 10.1016/j. chemphyslip.2019.03.011.

5. Valacchi G, Virgili F, Cervellati C, Pecorelli A. OxInflammation: From Subclinical Condition to Pathological Biomarker. Front Physiol. 2018; 9: 858. DOI: 10.3389/fphys.2018.00858.

6. Hawkins CL, Davies MJ. Detection, identification, and quantification of oxidative protein modifications. Journal of Biological Chemistry. 2019; 294 (51): 19683-708.

7. Murray RZ, West ZE, Cowin AJ, Farrugia BL. Development and use of biomaterials as wound healing therapies. Burns Trauma 2019; 7: 2. DOI: 10.1186/s41038-018-0139-7.

8. Осиков М. В. Влияние эритропоэтина на процессы свободнорадикального окисления и экспрессию гликопротеинов в тромбоцитах при хронической почечной недостаточности. Бюллетень экспериментальной биологии и медицины. 2014; 157 (1): 30-33.

9. Осиков М. В., Телешева Л. Ф., Агеев Ю. И. Влияние эритропоэтина на апоптоз лимфоцитов при экспериментальной хронической почечной недостаточности. Бюллетень экспериментальной биологии и медицины. 2015; 3: 326-9.

10. Осиков М. В. Роль орозомукоида в регуляции активности систем плазменного протеолиза при экспериментальной почечной недостаточности. Бюллетень экспериментальной биологии и медицины. 2009; 7: 27-30.

11. Osikov MV, Telesheva LF, Ageev YI. Antioxidant effect of erythropoietin during experimental chronic renal failure. Bulletin of Experimental Biology and Medicine. 2015; 160 (2): 202-4.

12. Varoni EM, Soru C, Pluchino R, Intra C, Iriti M. The Impact of Melatonin in Research. Molecules. 2016; 21 (2): 240. DOl: 10.3390/molecules21020240.

13. Волчегорский И. А., Налимов А. Г., Яровинский В. Г.

Сопоставление различных подходов к определению продуктов ПОЛ в гептан-изопропанольных экстрактах крови. Вопросы медицинской химии. 1989; 35 (1): 127-31.

14. Фомина М. А., Абаленихина Ю. В. Способ комплексной оценки содержания продуктов окислительной модификации белков в тканях и биологических жидкостях: методические рекомендации. ГБОУ ВПО РязГМУ Минздрава. Рязань: РИО РязГМУ, 2014

15. Mitran MI, Nicolae I, Tampa M, Mitran Cl, Caruntu C, Sarbu MI, et al. Reactive Carbonyl Species as Potential Pro-Oxidant Factors Involved in Lichen Planus Pathogenesis. Metabolites. 2019; 9 (10): E213. DOI: 10.3390/metabo9100213.

16. Wei $C$, Ding $X$, Liu $C$, Pei $Y$, Zhong $Y$, Sun W. Mechanism of taurine in alleviating myocardial oxidative stress in rats after burn through p38 MAPK signaling pathway. Minerva Med. 2019; 110 (5): 472-75.

17. Jacob S, Herndon DN, Hawkins HK, Enkhbaatar P, Cox RA. Xanthine oxidase contributes to sustained airway epithelial oxidative stress after scald burn. International journal of burns and trauma. 2017; 7 (6): 98-106.

18. Klein GL. The role of the musculoskeletal system in post-burn hypermetabolism. Metabolism. 2019; 97: 81-86.

19. ErginTuncay M, Erkilıc A, Gunes A, Nural C, Erel O. A remarkable point for evaluating the severity of burns: Thiol-disulfide profile. Burns. 2019; 46 (4): 0305-4179(19)30638-2. DOI: 10.1016/j. burns.2019.10.013.

20. Lee YH, Bang ES, Lee JH, Lee JD, Kang DR, Hong J, Lee JM. Serum Concentrations of Trace Elements Zinc, Copper, Selenium, and Manganese in Critically III Patients. Biological Trace Element Research. 2019; 188 (2): 316-25.

21. Lindley LE, Stojadinovic O, Pastar I, Tomic-Canic M. Biology and Biomarkers for Wound Healing. Plastic and Reconstructive Surgery. 2016; 138 (3): 18-28.

22. Lee HJ, Jang YJ. Recent. Understandings of Biology, Prophylaxis and Treatment Strategies for Hypertrophic Scars and Keloids. International Journal of Molecular Sciences. 2018; 19 (3): 711. DOI: 10.3390/ijms19030711.

23. Yu H, Dickson EJ, Jung SR, Koh DS, Hille B. High membrane permeability for melatonin. The Journal of General Physiology. 2016; 147: 63-76.

24. Mayo JC, Aguado A, Cernuda-Cernuda R, Alvarez-Artime A, Cepas V, Quiros-Gonzalez I, et al. Melatonin uptake by cells: an answer to its relationship with glucose? Molecules. 2018; 23: e1999. DOI: 10.3390/molecules23081999.

25. Janjetovic Z, Jarrett SG, Lee EF, Duprey C, Reiter RJ, Slominski AT. Melatonin and its metabolites protect human melanocytes against 


\section{ORIGINAL RESEARCH I PATHOPHYSIOLOGY}

UVB-induced damage: Involvement of NRF2-mediated pathways. Scientific Reports. 2017; 7 (1): 1274. DOI: 10.1038/s41598-01701305-2.

26. Rusanova I, Martínez-Ruiz L, Florido Ja, Rodríguez-Santana C, Guerra-Librero A, Acuña-Castroviejo D, et al. Protective Effects of Melatonin on the Skin: Future Perspectives. International Journal of Molecular Sciences. 2019; 20 (19): 4948. DOI: 10.3390/ ijms20194948.

27. Dai J, Choo MK, Park JM, Fisher DE. Topical ROR inverse agonists suppress inflammation in mouse models of atopic dermatitis and acute irritant dermatitis. Journal of Investigative Dermatology. 2017; 137: 2523-31.
28. Slominski AT, Semak I, Fischer TW, Kim TK, Kleszczyński K, Hardeland R, et al. Metabolism of melatonin in the skin: Why is it important? Experimental Dermatology. 2017; 26: 563-8.

29. Janjetovic Z, Jarrett SG, Lee EF, Duprey C, Reiter RJ, Slominski AT. Melatonin and its metabolites protect human melanocytes against UVB-induced damage: Involvement of NRF2-mediated pathways. Scientific Reports. 2017; 7 (1): 1274. DOI: 10.1038/s41598-01701305-2.

30. Reiter RJ, Rosales-Corral S, Tan DX, Jou MJ, Galano A, Xu B. Melatonin as a mitochondria-targeted antioxidant: one of evolution's best ideas. Cellular and Molecular Life Sciences. 2017; 74 (21): 3863-81. 